\title{
Pasture species and drought impact on milk yield 1. Milk yield responses in the Waikato
}

\author{
E.R. THOM, D.A. CLARK, V.T. VAN VUGHT and C.D. WAUGH \\ Dairying Research Corporation, Private Bag 3123, Hamilton
}

\begin{abstract}
Milksolids (MS) production of Jersey cows grazing different pasture species mixtures over summer and autumn is described for the first two years of a 4-year trial. Four pasture mixtures were established after cultivation in autumn 1996, and were compared with existing ryegrass-white clover pastures. The mixtures were: (1) high-endophyte perennial ryegrass-white clover (2) tall fescue, phalaris, cocksfoot, white clover, red clover (3) same as (2) plus paspalum (4) endophyte-free ryegrass, timothy, white clover, red clover and (5) existing high-endophyte ryegrass, white clover. Milk tests were in January-February of 1997 and 1998. Cows were offered a single pasture allowance. Cows on high-endophyte ryegrass mixtures consistently produced low MS yields compared with those on tall fescue mixtures and endophyte-free ryegrass. In 1998, responses for cows grazing ryegrass-white clover (5 and 1 ) were significantly less than from tall fescue-based pastures ( 2 and 3) ( 0.74 vs. $0.86 \mathrm{~kg} / \mathrm{cow} /$ day), and responses from cows on ryegrass/timothy based pastures (4), were better than for all others $(0.96$ $\mathrm{kg} / \mathrm{cow} /$ day). Important determinants of the MS responses were the high rust infection and low contents of white clover in the high-endophyte ryegrass (1) pastures, and the high contents of red clover in the tall fescue and endophyte-free ryegrass-based pastures.
\end{abstract}

Keywords: cocksfoot, cow grazing, irrigation, milk production, pasture quality, perennial ryegrass, phalaris, red clover, tall fescue, timothy, triple mix, white clover

\section{Introduction}

The New Zealand dairy industry has identified the likely benefits to farm profitability of improving summerautumn feed supply and the amount of milk processed over this period (McGrath et al. 1998). Peak milksolids (MS) production coincides with peak ryegrass growth in October-November and is followed by a steep decline of up to $19 \%$ per month (Exton et al. 1996) as feed supply and quality from ryegrass-white clover pastures are compromised by low rainfall and high summer temperatures. Penno et al. (1995) suggested the decline in MS could be reduced to 4-7\% per month over summerautumn for high-performing dairy cows with no feeding restrictions.

Irrigation is one method of improving summerautumn feed supply and quality, and MS (Hutton 1974), but recent work (Thomson 1996; Hainsworth \& Thomson 1997) indicates the extra dry matter produced and consumed must be of high quality to improve MS production. Another method may be the use of alternative drought-tolerant grasses such as tall fescue, phalaris and cocksfoot (Hainsworth et al. 1991; Moloney 1991). The development of "triple mixes" and endophyte-free ryegrass-timothy mixtures with white and red clover has been advocated in Northland, Waikato, Manawatu and Canterbury as alternatives to compare with existing ryegrass-dominant dairy pastures in these regions. However, short-term and farmlet trials in Taranaki have produced variable MS responses (Hainsworth \& Thomson 1997; McCallum et al. 1992), and milk production data from other districts are sparse.

This paper describes the results for the first two years of a 4-year component trial examining the effects of pasture species mixtures and irrigation on pasture quality and MS production over summer-autumn in the Waikato.

\section{Materials and methods}

\section{Site}

Eight 1.25 ha blocks containing 50.25 ha paddocks were selected on No. 5 Dairy at the Dairying Research Corporation. The pastures had been intensively grazed by cows and received regular applications of potassic superphosphate and lime. Standard soil quick tests in February 1997 showed overall soil fertility was high $(\mathrm{P}=29, \mathrm{~K}=11, \mathrm{pH}=6.0)$. Soils were mainly Te Kowhai clay loams and Bruntwood silt loams.

\section{Pasture treatments and design}

A $2 \times 5$ split plot factorial design with 4 blocks (reps) was used in which irrigation (+ or - ) were the main plots with 5 pasture treatments randomly allocated as subplots within each main plot. Pasture treatments were: (1) new high-endophyte perennial ryegrasswhite clover as control (HER); (2) tall fescue, phalaris, 
cocksfoot, white clover, red clover (TM); (3) same as (2) plus paspalum (TMP); (4) endophytefree ryegrass, timothy, white clover, red clover (LER) and (5) existing high-endophyte ryegrass, white clover (EP) as another control (Table 1).

Paddocks sown to new pasture mixes were ploughed and rolled in late February 1996, after spraying with glyphosate at $1.44 \mathrm{~kg}$ a.i./ha (equivalent to 4 1/ha of Roundup ${ }^{\circledR}$ ) plus penetrant. A power-harrow with seedbox attached was used to cultivate and sow the various pasture mixes from 12-19 March 1996.

\section{Milk testing}

Milksolids (MS) production was measured in January-February of each year. Cows on the 10 pasture $x$ irrigation treatments were fed at one pasture allowance (30 kg DM/ cow/day).

Milk yield and composition (protein and fat) (Milkoscan), for each cow, were measured on composite samples collected at consecutive evening and morning milkings. Milk yield and composition were recorded twice during the uniformity period and the first week of each test period, followed by five tests over the last five days of each period.

\section{Grazing management}

Herds of 10 Jersey cows, balanced for current MS production, age, liveweight and stage of lactation, were allocated to the 10 pasture treatments for 12-day test periods.

Before each test period all cows grazed together for a 7-day uniformity period on ryegrass-white clover pastures. Replicates were grazed in sequence. Each paddock was grazed for 3 days.

Three to four weeks before milk testing, grazing management aimed at removing excessive seed-head and increasing green leaf availability either by topping or follow-up grazing with dry cows. Average residuals over the trial were $1900 \mathrm{~kg} \mathrm{DM} / \mathrm{ha}$ in $1997 \mathrm{and} 2300 \mathrm{~kg}$ DM/ha in 1998.

\section{Pasture botanical composition}

Before grazing each milk test period herbage was clipped to ground level and botanical composition of component species determined.

\section{Pasture chemical composition}

Herbage samples from each paddock to be grazed during milk test periods were cut to ground level. In 1997, whole pasture and green leaf samples were separated for each paddock, but in 1998 because of lack of time, only a bulk sample of green leaf over the four treatment replicates was analysed.

Analyses conducted on separate 100 to $150 \mathrm{~g}$ subsamples of fresh herbage were (i) in vitro organic matter digestibility (IVD) - sample dried at $95^{\circ} \mathrm{C}$ for 12 $\mathrm{h}$ (ii) nitrogen $(\mathrm{N})$, sodium $(\mathrm{Na})$, potassium $(\mathrm{K})$, calcium $(\mathrm{Ca})$, magnesium $(\mathrm{Mg})$ and phosphorus $(\mathrm{P})$ contents, neutral detergent fibre (NDF) and acid detergent fibre (ADF) contents - sample dried at $95^{\circ} \mathrm{C}$ for $36 \mathrm{~h}$ (iii) soluble carbohydrates - sample freeze dried. Standard procedures were used.

\section{Irrigation}

Soil water contents were monitored weekly on indicator paddocks and 3-weekly on all other paddocks from November to May using a Time Domain Reflectometer (TDR) with probes permanently installed to $15 \mathrm{~cm}$ depth.

Field capacity of the trial site was about $52 \%$ and at plant wilting point was about $24 \%$ soil water content. Irrigation was applied when the soil moisture content was about $38 \%$, (50\% available soil water), to ensure irrigated pastures were never close to wilting point. 


\section{Argentine stem weevil control}

Argentine stem weevil egg and larval numbers were counted in late December 1996 and early January 1997 on timothy and endophyte-free ryegrasses. Because numbers in January 1997 were high, all trial paddocks were sprayed with $0.48 \mathrm{~kg}$ a.i. of oxamyl insecticide (equivalent to 2 1/ha of Vydate L) on 13 January 1997. No control measures were used in 1998.

\section{Statistical analysis}

Pasture data were analysed using a split plot analysis of variance model generated by Genstat 5. Milk production and composition data were analysed by SAS 6.12 using the uniformity data in an analysis of covariance, and the data from individual cows as replicates.

\section{Results}

\section{Climate and soil water content}

Rainfall during summer 1995-96 (December-February) was $35 \%$ above average $(241 \mathrm{~mm})$ giving adequate soil moisture conditions for March sowing. The 1996-97 and 1997-98 summers were drier than normal, being $29 \%$, and $18 \%$ below average, respectively. Only $20 \mathrm{~mm}$ of rain fell on 8 rain days from 3 January to 17 February 1997, and $37 \mathrm{~mm}$ rain from 27 December 1997 to 21 February 1998 on 16 rain days. Average soil water contents on non-irrigated paddocks fell below plant wilting point in January (18\%) and February 1997 (19\%), and early January (22\%) and late January 1998 (18\%). Comparable soil water contents on irrigated areas were $42,39,32$ and $32 \%$, respectively. January-February irrigation in 1997 was $144 \mathrm{~mm}$ compared with $163 \mathrm{~mm}$ in 1998 .

\section{Milk production and composition \\ Irrigation}

Irrigation increased MS production by $3.7 \%(\mathrm{P}<0.05)$ in 1998, but had no effect in 1997 (Table 2). Irrigation consistently increased milk fat $\%$; milk protein $\%$ responded positively to irrigation in 1997 but negatively in 1998, with overall differences small but significant $(\mathrm{P}<0.05)$ in both cases.

\section{Pasture species mixture}

Cows on HER pastures produced the lowest MS yield in 1997 and again in 1998 (Table 3) along with cows on EP pastures. Milk fat $\%$ was unaffected by pasture, but a trend for higher fat $\%$ and protein $\%$ in milk from cows on LER pastures was reflected in a higher MS yield in 1998 (Table 3). Cows on triple mix pastures (TM and TMP) also produced more MS than those on ryegrassdominant pastures (EP and HER). There were no significant species $\mathrm{x}$ irrigation interactions and trends in milk yield (1/cow/day) followed those of MS.
Table 2 Effects of irrigation on milksolids yield (kg MS/cow/day) and milk fat and protein\% in January-February 1997 and 1998.

\begin{tabular}{rccc}
\hline & Irrigation & No irrigation & SED \\
\hline $\begin{array}{r}\text { Milksolids } \\
1997\end{array}$ & 1.02 & 1.01 & $0.021^{\mathrm{NS}}$ \\
1998 & 0.85 & 0.82 & $0.015^{*}$ \\
Fat\% & & & \\
1997 & 6.44 & 6.19 & $0.104^{*}$ \\
1998 & 6.02 & 5.81 & $0.088^{*}$ \\
Protein\% & & & \\
1997 & 4.15 & 4.06 & $0.026^{* *}$ \\
1998 & 3.76 & 3.80 & $0.018^{*}$ \\
\hline
\end{tabular}

NS = not significant; ${ }^{*}=\mathrm{P}<0.05 ;{ }^{* *}=\mathrm{P}<0.01$

Table 3 Effect of pasture species mixture on milksolids yield ( $\mathrm{kg}$ MS/cow/day) and milk composition (fat\%, protein \%) in January-February 1997 and 1998.

\begin{tabular}{|c|c|c|c|c|c|c|}
\hline & \multicolumn{6}{|c|}{--------------- Pasture mixture } \\
\hline & EP & HER & TM & TMP & LER & SED \\
\hline \multicolumn{7}{|l|}{1997} \\
\hline Milksolids & 1.05 & 0.96 & 1.00 & 1.05 & 1.01 & $0.03^{*}$ \\
\hline Fat $\%$ & 6.20 & 6.59 & 6.31 & 6.14 & 6.33 & $0.17^{\mathrm{NS}}$ \\
\hline Protein\% & 4.12 & 4.12 & 4.15 & 4.00 & 4.18 & $0.04^{\star \star *}$ \\
\hline \multicolumn{7}{|l|}{1998} \\
\hline Milksolids & 0.71 & 0.76 & 0.83 & 0.89 & 0.96 & $0.03^{*}$ \\
\hline Fat $\%$ & 5.84 & 5.99 & 5.88 & 5.85 & 6.02 & $0.14^{\mathrm{NS}}$ \\
\hline Protein \% & 3.77 & 3.79 & 3.75 & 3.77 & 3.83 & $0.03^{*}$ \\
\hline
\end{tabular}

NS = not significant; ${ }^{*}=\mathrm{P}<0.05 ;{ }^{* * *} \mathrm{P}<0.001$.

${ }^{a} \mathrm{EP}=$ existing high-endophyte ryegrass-white clover; $\mathrm{HER}=$ high-endophyte ryegrass-white clover; $\mathrm{TM}=$ tall fescue, phalaris, cocksfoot, white clover, red clover; TMP = tall fescue, phalaris, cocksfoot, paspalum, white clover, red clover; LER = endophyte-free ryegrass, timothy, white clover, red clover.

\section{Pasture botanical composition and yield}

Irrigation rarely affected pasture botanical composition. Exceptions were in late February of 1997 and 1998 when, overall, irrigation increased ryegrass contents by $12 \%$ of DM. Dead material was reduced in irrigated compared with non-irrigated pastures especially in February 1998 (19 vs. 42\% of DM, SED $\left.=3.7^{* *}\right)$.

White clover contents in summer were low throughout the trial, averaging 6\% of DM in EP and 3\% on other pastures. Red clover was the dominant legume in TM, TMP and LER pastures in February 1997, representing 10,10 and $22 \%$ of DM of TM, TMP and LER pastures, respectively, and in January 1998 when comparable data were 26,20 and $34 \%$ of DM.

Tall fescue in triple mix pastures in summer ranged from 21 to $24 \%$ of DM. Phalaris was always $<10 \%$ of DM. Paspalum was never detected in TMP pastures. On average, volunteer ryegrass accounted for $12 \%$ of DM in triple mix pastures in summer. 
Ryegrass-based pastures (EP, HER and LER) had average contents of ryegrass in summer of $42 \%$ of DM in 1997 and $26 \%$ in 1998 , and average contents of dead material of $20 \%$; triple mix pasture usually contained less dead material at about $12 \%$ of DM. Timothy steadily increased in LER pastures from about $5 \%$ of DM in summer 1997 to $16 \%$ in summer 1998 , mainly because of a large response to irrigation in February 1998 (27 vs $4 \%$ of DM, SED $=2.82^{* *}$ ).

Averaged over all pasture mixtures, irrigation improved summer DM yield by $1500 \mathrm{~kg} / \mathrm{ha}$ in $1996-97$ and $1100 \mathrm{~kg} / \mathrm{ha}$ in $1997-98$.

\section{Pasture digestibility and chemical composition}

Irrigation usually had small effects on pasture quality parameters in summer. Pasture species had a large effect on quality parameters, as illustrated for January 1997 (Table 4). trends in 1998, as illustrated for 1997 (Table 4), but the nitrogen contents of EP and HER pastures were lower $(2.1 \%$ of DM) than for the other pastures $(2.5 \%)$.

\section{Discussion}

Irrigation generally had small effects $(<4 \%)$ on MS production, reflecting little change in botanical composition, digestibility and chemical composition of pasture in response to irrigation. Irrigation produced an extra $1300 \mathrm{~kg} \mathrm{DM} / \mathrm{ha}$ in each of two summers. Assuming a response of $50 \mathrm{~g} \mathrm{MS} / \mathrm{kg} \mathrm{DM}$, another $65 \mathrm{~kg} \mathrm{MS} / \mathrm{ha}$ could be produced. Our results support those of Thomson (1996) for high-endophyte ryegrass pastures, but conflict with Hutton (1974) who reported that digestibility differences up to $9 \%$ contributed to an extra $100 \mathrm{~kg} / \mathrm{ha}$ of milkfat from cows grazing irrigated pastures stocked at $4.9 \mathrm{cows} / \mathrm{ha}$.

Few trials have measured milk production

Table 4 Effects of pasture species mixtures on in vitro digestibility (IVD) (\%), neutral detergent fibre (NDF), soluble carbohydrate (CARB), nitrogen $(\mathrm{N})$, calcium $(\mathrm{Ca})$ and magnesium $(\mathrm{Mg})$ contents $(\%)$, in whole pasture and green leaf in January 1997.

\begin{tabular}{llllllll}
\hline \multicolumn{2}{l}{ Pasture $^{2}$ mixture } & & & & & & \\
& & EP & HER & TM & TMP & LER & SED \\
\hline IVD & (whole) & 72 & 76 & 69 & 70 & 72 & $1.0^{* * *}$ \\
& (leaf) & 75 & 75 & 68 & 71 & 72 & $0.9^{* * *}$ \\
NDF & (whole) & 47 & 51 & 48 & 51 & 49 & $1.0^{* *}$ \\
& (leaf) & 42 & 49 & 46 & 46 & 44 & $1.1^{* * *}$ \\
CARB & (whole) & 13.2 & 14.9 & 11.1 & 11.9 & 13.5 & $0.6^{* * *}$ \\
& (leaf) & 10.2 & 11.3 & 7.8 & 8.6 & 9.95 & $0.6^{* * *}$ \\
$\mathrm{~N}$ & (whole) & 2.7 & 2.6 & 2.8 & 2.7 & 2.7 & $0.15^{\text {NS }}$ \\
& (leaf) & 3.7 & 3.3 & 3.7 & 3.6 & 3.6 & $0.11^{* *}$ \\
$\mathrm{Ca}$ & (whole) & 0.61 & 0.43 & 0.62 & 0.56 & 0.58 & $0.05^{* *}$ \\
& (leaf) & 0.74 & 0.52 & 0.78 & 0.78 & 0.81 & $0.06^{* * *}$ \\
$\mathrm{Mg}$ & (whole) & 0.22 & 0.19 & 0.26 & 0.24 & 0.21 & $0.01^{* * *}$ \\
& (leaf) & 0.26 & 0.23 & 0.30 & 0.30 & 0.26 & $0.01^{* * *}$ \\
\hline
\end{tabular}

NS $=$ not significant; ${ }^{* *}=\mathrm{P}<0.01 ;{ }^{* * *} \mathrm{P}<0.001$.

${ }^{a}$ EP = existing high-endophyte ryegrass-white clover; $H E R=$ highendophyte ryegrass - white clover; $\mathrm{TM}=$ tall fescue, phalaris, cocksfoot, white clover, red clover; TMP = tall fescue, phalaris, cocksfoot, paspalum, white clover, red clover; LER = endophyte-free ryegrass, timothy, white clover, red clover.

The composition of HER whole pasture and green leaf samples were often different to the others; with higher levels of NDF and lower levels of $\mathrm{N}$ in green leaf, low $\mathrm{Ca}$ and $\mathrm{Mg}$ levels in whole pasture and green leaf but high levels of soluble sugar, relative to other pastures (Table 4). Features of triple mix-based pastures were lower digestibility and levels of soluble carbohydrate than ryegrass-based pastures.

Whole-pasture digestibility was about 5 units lower in January 1998 than in the previous year, averaging $67 \%$, with no differences among pasture or irrigation treatments. Soluble carbohydrate levels showed the same responses to alternative pasture species. Most research results from short-term and farmlet trials have been collected in Taranaki in the 1980s and 1990s (Hainsworth \& Thomson 1997), and in the Waikato "More Summer Milk" farm demonstration programme (Exton et al. 1996). In short-term Taranaki trials and in the current tests, pastures were fed at similar allowances, so that responses could be measured in terms of production per cow rather than per hectare. Herbage mass during milk test periods ranged from 3050 to 3700 $\mathrm{kg} \mathrm{DM} / \mathrm{ha}$ on irrigated areas and from 2850 to $3700 \mathrm{~kg} \mathrm{DM} / \mathrm{ha}$ on non-irrigated areas, and were unlikely to restrict cow intake.

Overall MS responses were lower in 1998 than in 1997, reflecting the more prolonged dry period in summer and the lower digestibility in the second year (67 vs $72 \%$ ). HER pastures were based on a 20-year-old cultivar, Grasslands Nui, which is intolerant of the current races of crown rust (Thom et al. 1998), and was severely infected in summer 1998 . Low palatability of such pastures may affect animal production (e.g., Lowe et al. 1983), and was probably an important factor reducing MS production from HER pastures. TM, TMP and LER pastures all contained red clover whereas HER and EP did not. Average content of red clover for the former was about twice as high in $1998(27 \%)$ as in $1997(14 \%$ of DM), when MS production of cows grazing TM, TMP and LER pastures were superior (Table 3 ), reflecting the milk production potential of red clover (O'Brien \& Vermazen 1989).

Another possible influence on MS production was that HER and EP pastures contained endophyte while 
the others did not, although we have not shown large effects of endophyte on MS production (Thom et al. 1997). A further possible confounding factor was that timothy accounted for up to $27 \%$ of DM in some LER pastures and research by Hainsworth \& Thomson (1997) has shown timothy has a high milk production potential, similar to that of white clover (1.24 kg MS/cow/day) and greater than the average for tall fescue, cocksfoot and ryegrass pastures ( $1.10 \mathrm{~kg} \mathrm{MS} / \mathrm{cow} /$ day).

The 1997 finding of only small differences in MS production off existing ryegrass-based pastures compared with those containing tall fescue (Table 3) was similar to that of Thomson \& Barnes (1990). However, in 1998 when a prolonged dry period occurred, cows on drought-tolerant species (TM and TMP) had better MS production than those grazing ryegrass (EP and HER). The tendency for better MS responses off tall fescue-based pastures during droughts is supported by the work of Thomson et al. (1988) when milk production was greater in the only drought year in a 4year trial. Exton et al. (1996), reporting an on-farm demonstration, found superior MS production on one of three farms utilising a triple mix pasture on a droughtprone soil.

\section{Conclusions}

1. Irrigation had small effects on pasture quality and MS production. Irrigation will increase MS production by providing extra dry matter over summer (see Barker et al. 1998), rather than by major changes in pasture quality.

2. Species mixture had strong effects on pasture quality and MS production. In this experiment red clover content had a positive effect and rust infection on ryegrass had a negative effect on MS production.

\section{ACKNOWLEDGEMENTS}

We are grateful for the technical assistance provided by Helen Simons, Roslyn McCabe and Elizabeth Grayling; Michael Bennenbroek organised and assisted with the establishment of the pastures; Pat Laboyrie for grazing management and irrigation requirements; Rhonda Hooper for statistical analysis; Alec McGowan (AgResearch) for maintaining the TDR; Sergio Marshall (AgResearch) for advice on Argentine stem weevil control; The Foundation for Research, Science and Technology for funding.

\section{REFERENCES}

Barker, D.J.; Clark, D.A.; Thom, E.R.; Couchman, J.; Burton, R.; Dymock, N. 1998. Pasture species and drought impact on milk yield 2. Predicted milk yield at four sites. Proceedings of the New Zealand Grassland Association 60: 45-50.

Exton, P.R.; Dawson, J.E.; Thomson, N.A.; Moloney, S. 1996. More summer milk - progress to date. Proceedings of the Ruakura Farmers' Conference 48: 34-41.

Hainsworth, R.J.; Thomson, N.A. 1997. Milk production from different pastures: Taranaki experiences. Dairyfarming Annual 49: 134-141.

Hainsworth, R.J.; Thomson, N.A.; McCallum, D.A.; Judd, T.G. 1991. Evaluation of dryland species and new ryegrass cultivars to increase pasture productivity in coastal Taranaki. Proceedings of the New Zealand Grassland Association 53: 55-58.

Hutton, J.B. 1974. The effect of irrigation on forage yield, dairy cow production and intake under intensive grazing conditions in New Zealand. Proceedings of the $19^{\text {th }}$ Dairy Congress, New Delhi, IE: 73-74.

Lowe, K.F.; Bowdler, T.M.; Ostrowski, H.; Stillman, S.L. 1983. Comparison of the yield, nitrogen and phosphorus content, and rust infection (Puccinia coronata) of irrigated ryegrass swards in South Eastern Queensland. Australian journal of agriculture and animal husbandry 23: 294-301.

McCallum, D.A.; Thomson, N.A.; Thom, E.R. 1992. The place of tall fescue in intensive dairying. Proceedings of the Ruakura Farmers' Conference 44: 93-97.

McGrath, D.F.; Dawson, J.E.; Thomson, N.A.; Simons, H. 1998. More summer milk - the opportunities identified. Proceedings of the Ruakura Farmers' Conference 50: 85-94.

Moloney, S.C. 1991. Performance of tall fescue, cocksfoot and phalaris based pastures compared with perennial ryegrass, in on-farm trials. Proceedings of the New Zealand Grassland Association 53: 4146.

O’Brien, G.; Vermazen, R. 1989. A comparison between dairy cows productivity on 'high' clover and existing pasture systems. Dairy production research report, Dairy Research Institute, Ellinbank, Victoria, Australia.

Penno, J.W.; Thomson, N.A.; Bryant, A.M. 1995. Summer milk - supplementary feeding. Proceedings of the Ruakura Farmers' Conference 47: 17-24.

Thom, E.R.; Clark, D.A.; Waugh, C.D.; McCabe, R.J.; van Vught, V.T.; Koch, B.J.L. 1997. Effects of ryegrass endophyte and different white clover levels in pasture on milk production from dairy cows. pp. 443-445. In: C.W. Bacon \& N.S. Hill (eds.) Neotyphodium/Grass Interactions. New York and London: Plenum Press. 
Thom, E.R.; Waugh, C.D.; McCabe, R.J. 1998. Growth and persistence of perennial and hybrid ryegrasses when grazed by dairy cows in the central Waikato region of New Zealand. New Zealand journal of agricultural research 41: 477-486.

Thomson, N.A. 1996. Irrigation and pasture quality. Proceedings of the Ruakura Farmers' Conference 48: 58-66.

Thomson, N.A.; Barnes, M.L. 1990. Alternative pastures to old ryegrass-white clover for dairying. Dairyfarming Annual 42: 122-124.

Thomson, N.A.; Lagan, J.F.; McCallum, D.A.; Prestidge, R. 1988. An evaluation of Grasslands Roa tall fescue and Grasslands Maru phalaris for dairying. Proceedings of the New Zealand Grassland Association 49: 187-191. 